\title{
APPLICATION AND VALIDATION OF XBEACH FOR THREE DIFFERENT FIELD SITES
}

\author{
Annelies Bolle ${ }^{1}$ Peter Mercelis, Dano Roelvink ${ }^{2}$, Piet Haerens and Koen Trouw ${ }^{3}$
}

\begin{abstract}
The XBeach model has been applied for different field sites, each having its specific problems. Cases were ranging from typical 1D beach erosion tests during storm conditions (to compare with Durosta results) which were extended to full 2D models to include the effects of curved coasts. For these kind of applications the XBeach model proved to be at least as good as Durosta for the $1 \mathrm{D}$ cases, but also giving the opportunity to include the $2 \mathrm{D}$ effects. Other examples are situated on high energy coasts (with long swell waves). Applications there are for example the design of a new coastal protection scheme, but also the study of sedimentation patterns in a shallow harbour surrounded by breakwaters and beaches. XBeach proved to be a powerful tool to get insight into these complex situations.
\end{abstract}

Keywords: XBeach; sediment transport modelling; beach erosion; harbour sedimentation

\section{INTRODUCTION}

Recently a new coastal response model, XBeach, was developed for modelling the nearshore processes such as wave breaking, surf and swash zone processes, dune erosion, overwashing and breaching (Roelvink et al., 2009). The model solves coupled 2DH equations for wave propagation, flow, sediment transport and bottom changes, for varying (spectral) wave and flow boundary conditions. It resolves the wave-group and infragravity time scales, which are responsible for most of the swash and overwash motions, which thus can be modelled explicitly.

This paper presents the application and validation of the model for three different case studies: one for Ostend beach in Belgium and two others in Ghana, Elmina harbour and Ada beach. Each site having its specific problems, the added value of the XBeach model is illustrated. In Ostend the typical beach erosion during storm conditions is studied. 1D and 2D models are applied. In Ada a new coastal protection scheme is designed to protect against long period waves. At the third site, in Elmina, the sedimentation processes in and around the shallow harbour are studied with a 2D XBeach model.

\section{XBEACH MODEL}

XBeach is a two-dimensional model for wave propagation, long waves and mean flow, sediment transport and morphological changes of the nearshore area, beaches, dunes and backbarrier during storms. XBeach concurrently solves the time-dependent short wave action balance, the roller energy equations, the nonlinear shallow water equations of mass and momentum, sediment transport formulations and bed update on the scale of wave groups (Roelvink et al.,2009).

With respect to the wave action and roller equations, the directional distribution of the wave action density is taken into account in the model. The frequency domain is reduced to a single representative peak frequency, assuming a narrow banded incident spectrum. The wave action and roller energy are used to compute radiation stress (gradients) which are on the right-hand side of the nonlinear shallow water equations. Using these formulations it is possible to generate directionally-spread infragravity waves and time-varying currents. To include short wave-induced mass fluxes and return flows in shallow water, XBeach uses the Generalized Lagrangian Mean formulation (Andrews and McIntyre, 1978). Sediment transport rates are calculated using an advection-diffusion equation (Galapatti and Vreugdenhil, 1985). The equilibrium concentration source-sink term is calculated using the SoulsbyVan Rijn formulation (Soulsby, 1997).

The XBeach model can be applied to areas extending several kilometres in the longshore and about a kilometre (several surf zone widths) in the cross-shore. This limited extent implies that it needs boundary conditions of tidal- and wind/pressure-driven water levels, deeper-water (outside the surf zone) wave boundary conditions and bathymetry. The wave boundary conditions can be applied as time series of the instantaneous wave height including wave grouping, or alternatively, the time-steady wave forcing can be used (which may still result in unsteady currents and surface elevation) (Roelvink et al., 2009).

\footnotetext{
${ }^{1}$ International Marine and Dredging Consultants (IMDC nv), Coveliersstraat 15, 2600 Berchem, Belgium (Annelies.Bolle@imdc.be)

2 UNESCO-IHE Institute for Water Education, p.o. box 3015, 2601 DA Delft, the Netherlands

${ }^{3}$ Fides Engineering, Sint-Laureisstraat 69 D, 2018 Antwerp, Belgium
} 


\section{OSTEND}

Ostend is a major city on the Belgian coast. The city centre is situated below high water level and has historically been protected with sea dikes, or "hard" protection measures. The city also attracts a lot of tourists. To facilitate them apartment buildings have been constructed right on top of the sea dike to be able to enjoy the sea view. However, with regards to extreme storm conditions and rising sea levels, the coastal protection of this town demands attention. An artificial beach has been created in front of the sea dike to offer better protection against storms. Figure 1 shows a typical beach profile for Ostend: a rather steep beach in front of the sea dike with the apartments on top. During storms the beach erodes, causing higher waves to reach the dike, resulting in higher overtopping discharges which could threaten people and infrastructure. Reliable predictions of the beach morphology are essential to evaluate the coastal protection level and to undertake actions such as for example beach nourishment to maintain the beach or even evacuation of inhabitants during extreme storms.
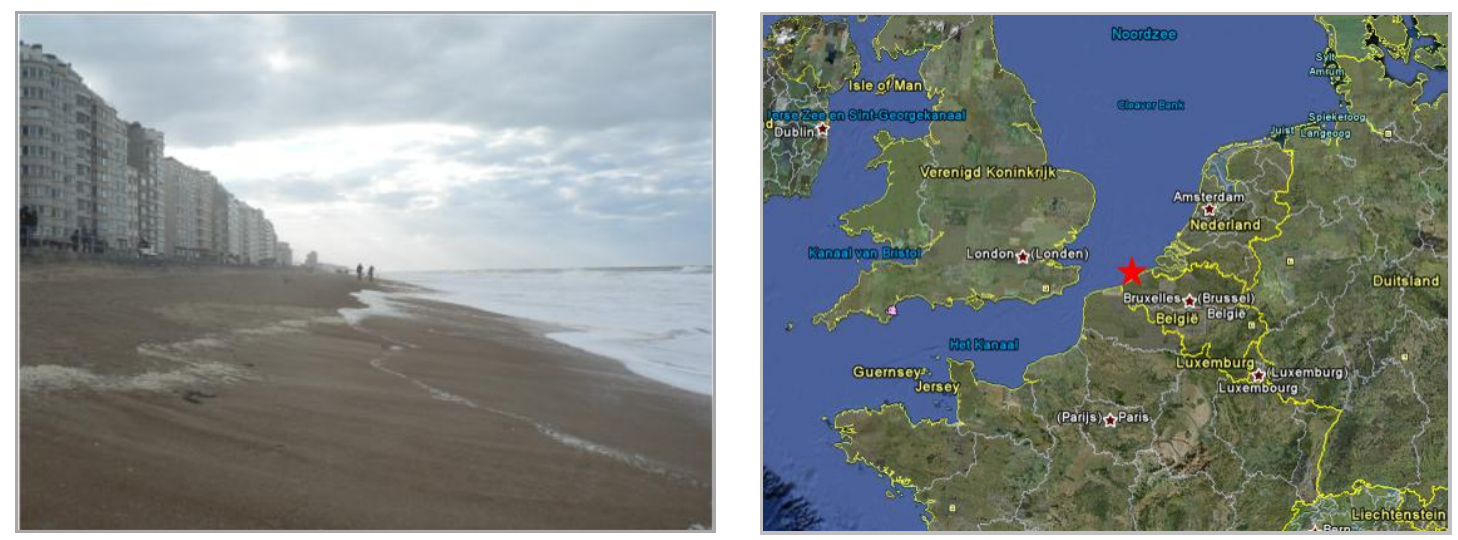

Figure 1. Field site 1: Ostend, Belgium (left: beach profile in front of Ostend centre, right: location in the southern North Sea).

In the Framework of the MICORE project (Morphological Impacts and Coastal Risks induced by Extreme storm events), Ostend city was selected as one of the 9 case studies across Europe. One of the specific objectives of this project is to test and develop reliable methods for numerical modeling of storm-induced morphological changes of a sandy coastal protection system. The XBeach software was selected as common tool for the different case studies and is compared to the historically used commercial packages. The models will be linked to wave and surge forecasting models to set-up a realtime warning system and to implement its usage within Civil Protection agencies.

\section{D model}

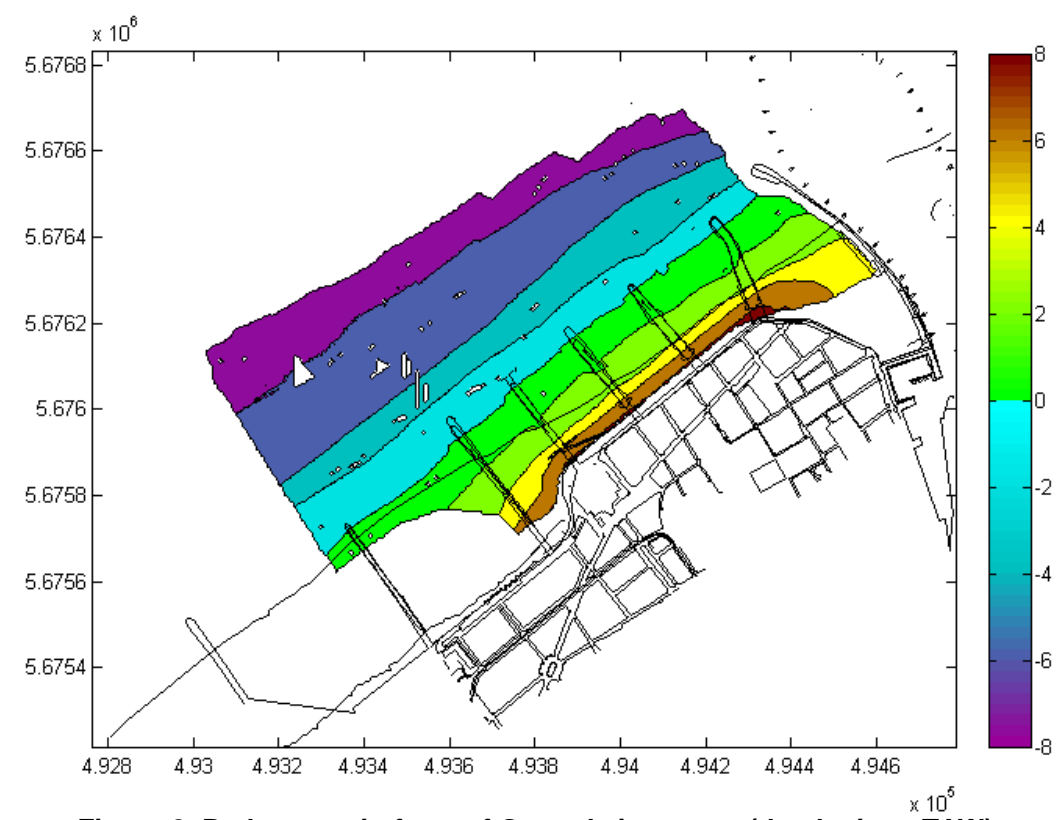

Figure 2. Bathymetry in front of Ostend city centre (depths in m TAW). 
Traditionally the beach erosion calculations have been performed with the Durosta model (Steetzel, 1993). This is however a 1D cross-shore model, which we expect to be less accurate for curved coasts. $2 \mathrm{D}$ effects are expected at Ostend since a part of the city protrudes into the sea, sticking out the further almost straight coastline. The artificial beach in front also shows these bends in the contour lines (see Figure 2). The main advantage of XBeach for this site is the possibility to work two-dimensional.

Since our main interest for this site is to improve the beach erosion predictions during storm events, a historical data set for Ostend beach has been used for the calibration of the models. For the storm of 8 to 10 November 2007 water levels and wave parameters have been measured nearshore at the Ostend "noodstrand" buoy throughout the storm. The water level varies between 0.5 and $6 \mathrm{~m}$ TAW (TAW = the reference level for heights in Belgium), showing a storm setup of almost $2 \mathrm{~m}$ (see Figure 3 ). The maximum wave height is about $3.5 \mathrm{~m}$, the corresponding peak wave period is $8.0 \mathrm{~s}$. The bathymetry and beach topography have been measured before and after the storm.
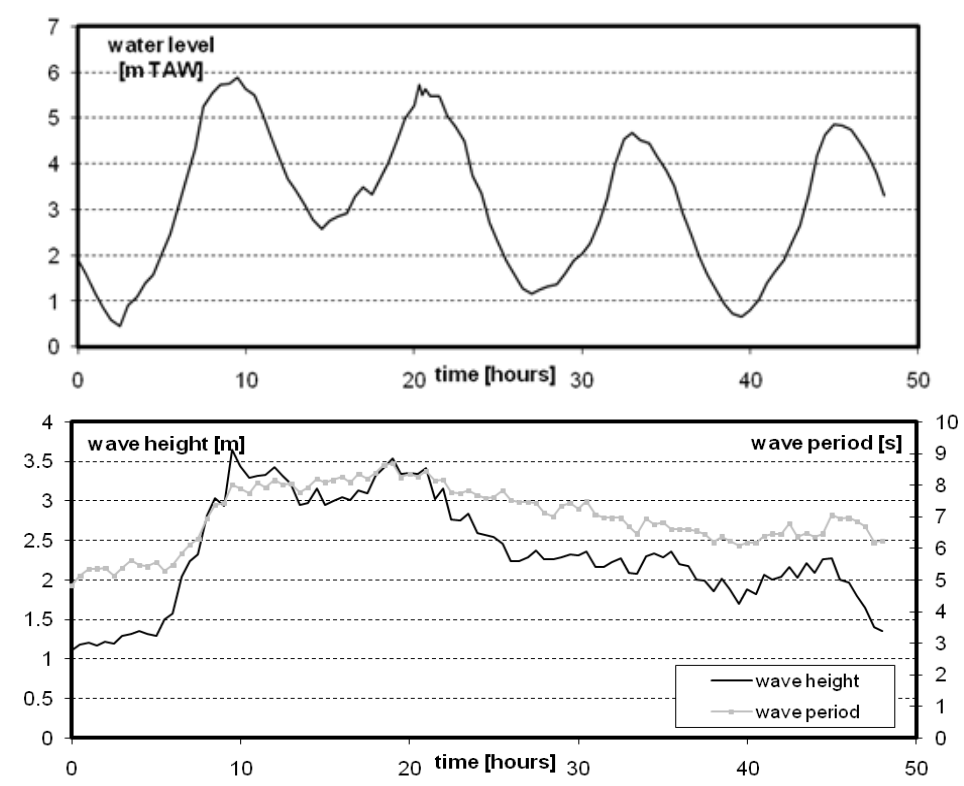

Figure 3. Hydrodynamic conditions at Ostend "noodstrand" buoy during the November 2007 storm.

Several models have been set up in XBeach. First of all a number of 1D models were constructed for the comparison with the existing Durosta models. The same gird spacing was applied, varying from $5 \mathrm{~m}$ offshore towards $1 \mathrm{~m}$ near the dike. All models have been run for the storm period of about 50 hours. The sea wall has been included in the XBeach model as a non-erodible layer. Further, default settings were applied, except from the amount of onshore transport, which has been used as a calibration parameter.

Figure 4 shows a comparison of the 1D XBeach results (in red) with the Durosta model results (in blue) and the measured bathymetry (full black line) for section 116. It can be seen that especially the beach erosion front (near the dyke) is better modelled with XBeach.

\begin{tabular}{|c|c|c|}
\hline Section number & Durosta & XBeach \\
\hline $113 a$ & 0.26 & 0.42 \\
\hline $114 a$ & 0.45 & 0.34 \\
\hline $114 b$ & 0.44 & 0.31 \\
\hline $115 a$ & 0.55 & 0.81 \\
\hline $115 b$ & 0.45 & 0.65 \\
\hline $116 a$ & 0.54 & 0.67 \\
\hline $116 \mathrm{~b}$ & 0.51 & 0.57 \\
\hline $117 a$ & 0.40 & 0.47 \\
\hline average & 0.45 & 0.53 \\
\hline
\end{tabular}

To allow a more quantitative comparison the Briar Skill Score (BSS) is applied. The BSS expresses how good the modelled bathymetry corresponds with the measured one. The closer the score comes to 
1 , the better the correspondence. An overview of the BSS for the Durosta and 1D XBeach models is given in Table 1. The average BSS for Durosta equals 0.45 , for XBeach the average BSS is 0.53 . Therefore, the performance of XBeach (1D) is in general at least as good as Durosta for the beach erosion calculations during storm events.

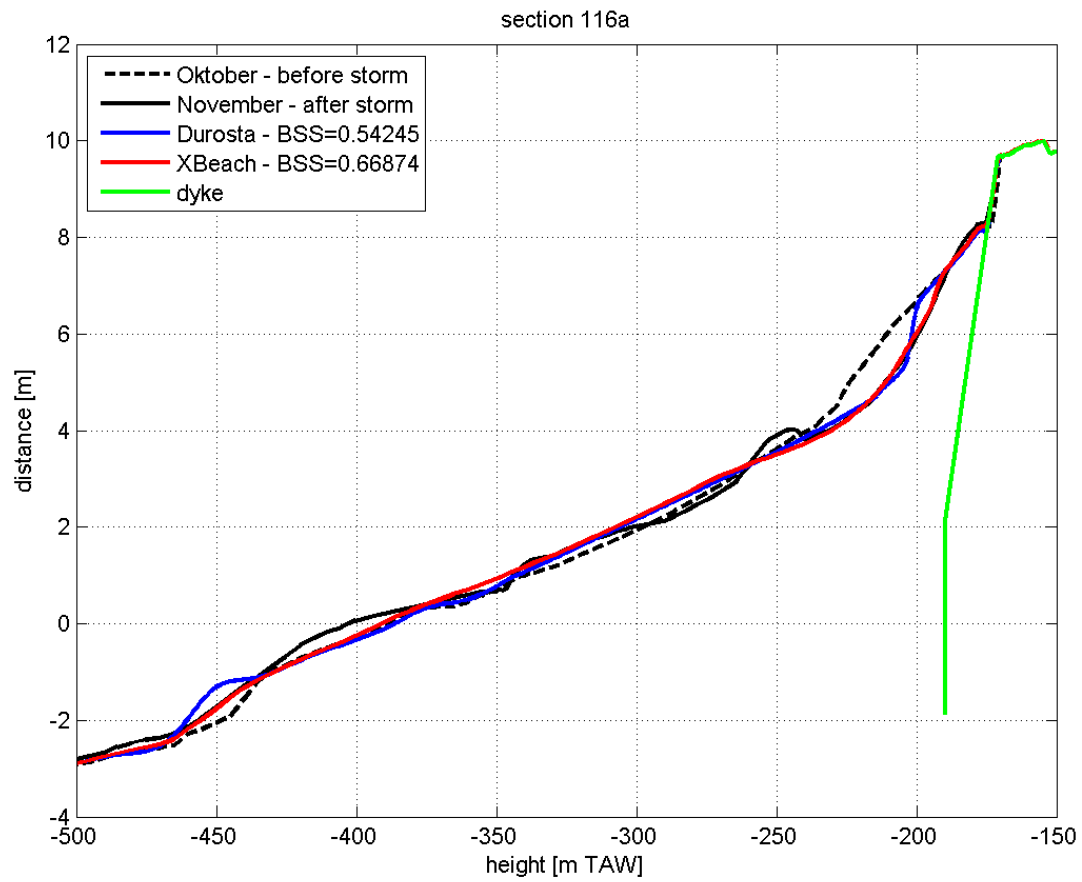

Figure 4. Comparison of 1D XBeach results (red) with the Durosta model results (blue) and the measured bathymetry (black) for section 116.

\section{D model}

Based on the same measurements, also a two-dimensional model has been set up for Ostend beach. A variable grid size has been applied: $\mathrm{dx}=5$ to $50 \mathrm{~m}$ (cross-shore), $\mathrm{dy}=20 \mathrm{~m}$ (alongshore), resulting in a total of $201 \times 43$ cells. The extend of this model is shown on figure 5. The same hydrodynamic conditions and settings as applied for the 1D models have been used.

The 2D erosion / sedimentation pattern is shown on figure 6 (erosion in blue, sedimentation in red). The 2D XBeach model does represent the higher amounts of erosion at the bends in the contour lines quite well, which are also seen in reality. This proves that the $2 \mathrm{D}$ model is able to resolve the $2 \mathrm{D}$ effects at these locations. As such, XBeach can improve the beach erosion predictions for Ostend.

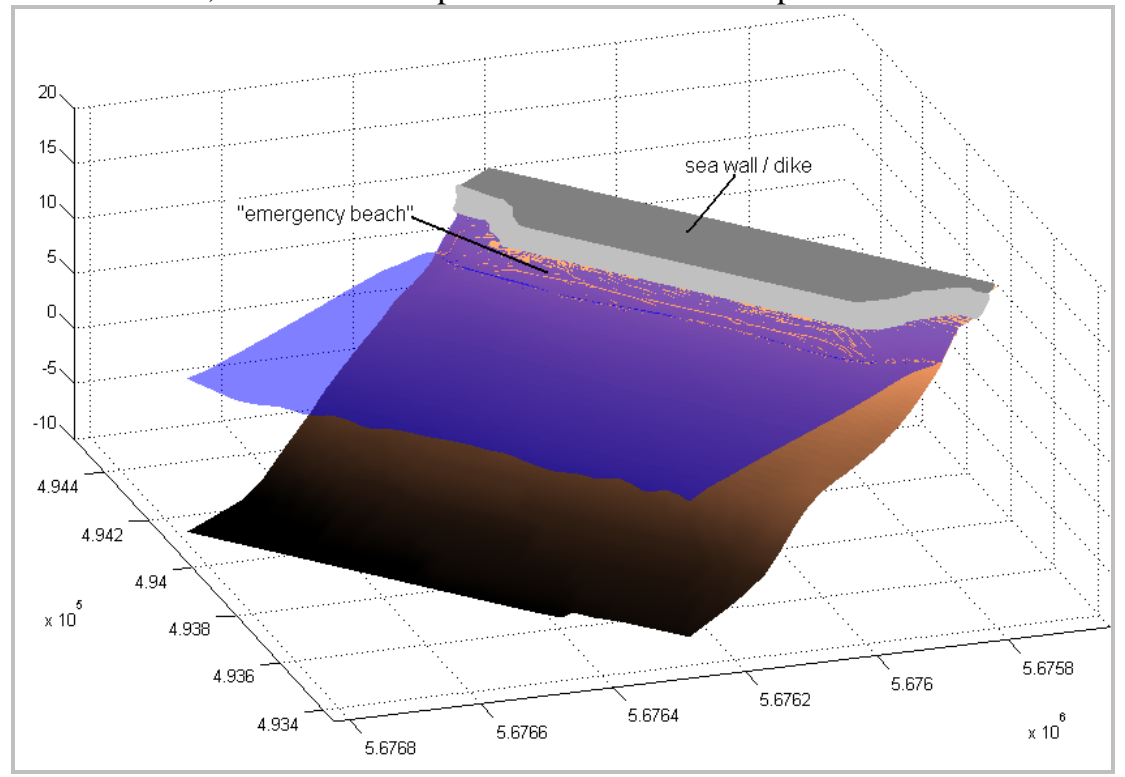

Figure 5. 2D XBeach model for Ostend beach. 


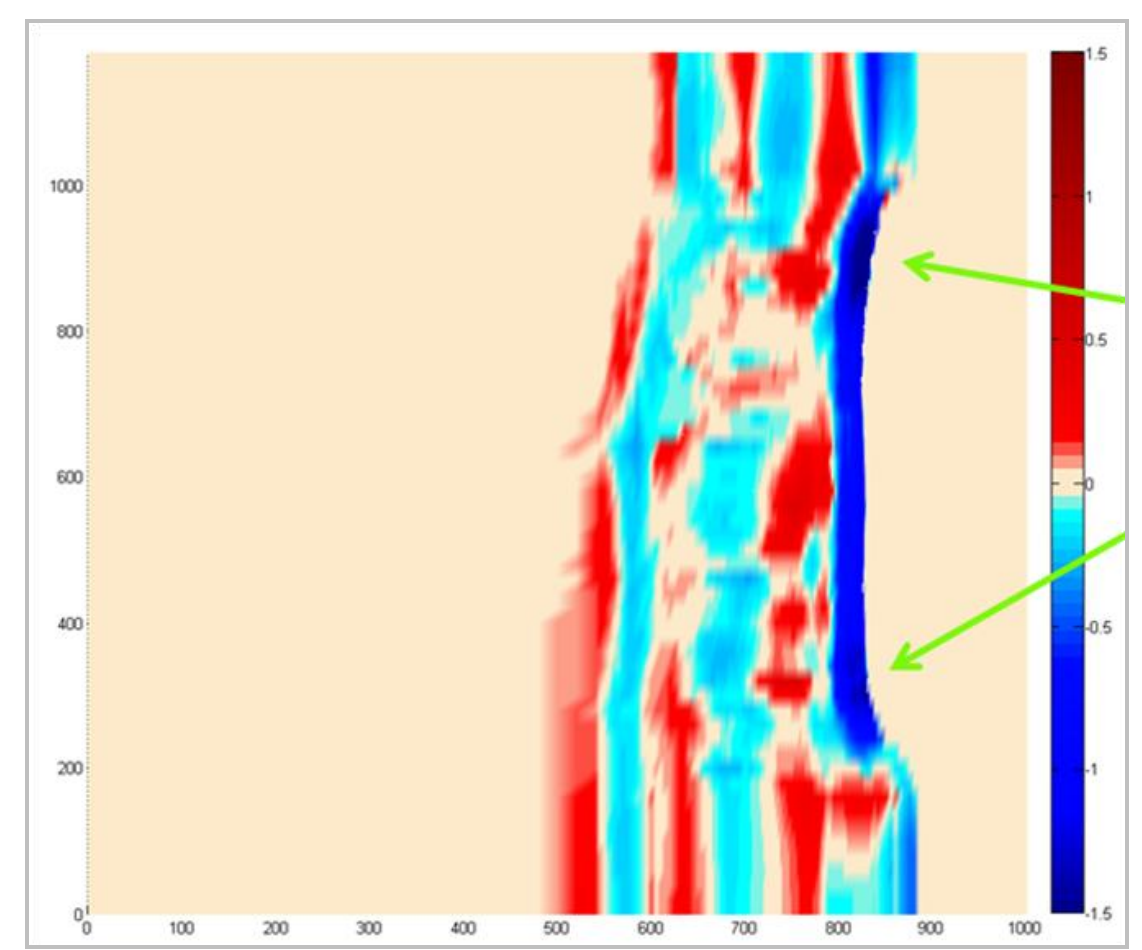

Figure 6. 2D erosion (blue) / sedimentation (red) pattern for Ostend beach, caused by the November 2007 storm event.

\section{ADA, GHANA}

Ada is a town in Ghana at the Volta estuary, known for its beaches and water sports. Located less than $100 \mathrm{~km}$ (to the east) from the capital Accra, this makes it an ideal holiday resort. However, the coast is severely eroding over several kilometres, threatening roads and properties (Figure 7). Whilst the wave climate does not show particular high waves, wave periods can be very long (15 to 20s), causing an important cross-shore sediment transport component.
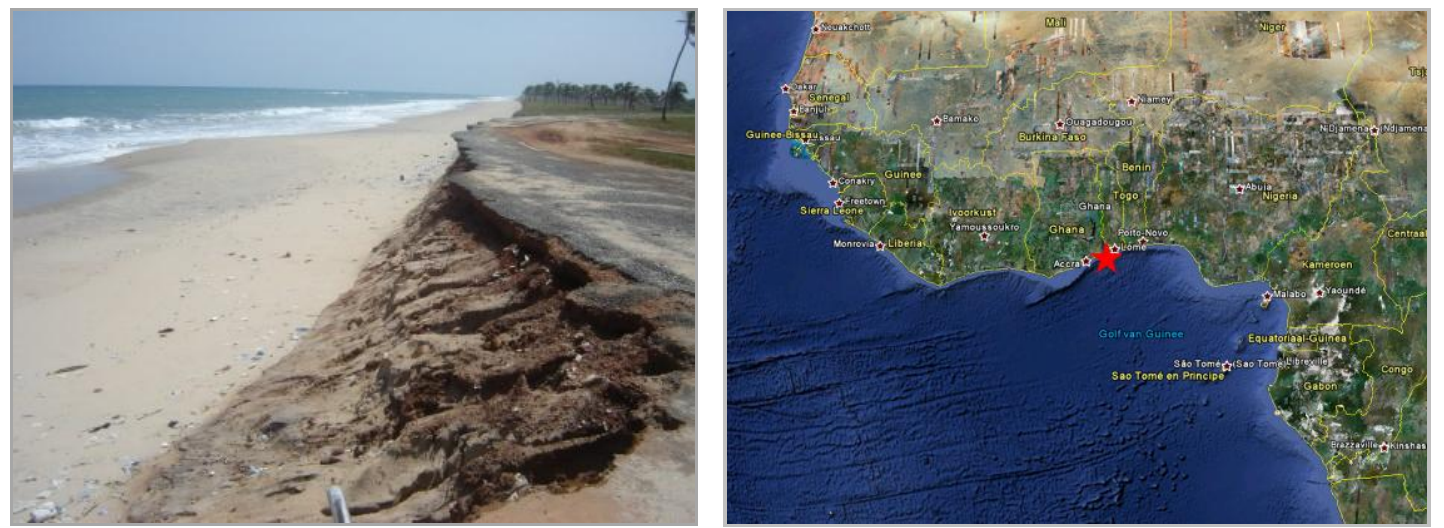

Figure 7. Field site 2: Ada, Ghana (left: coastal road falling into the sea, right: location in west Africa).

At the moment of writing this article, the topographic, bathymetric and hydrodynamic surveys were still going on, which meant no data were available yet to start the sediment transport and beach erosion modelling. Aim would be to test the newly designed coastal protection scheme under the high energy and long period swell waves. For more details about the Ada project and the planned coastal protection scheme, reference is made to Koen Trouw et al., 2010. 


\section{ELMINA, GHANA}

Also this field site is located in Ghana, about 140km west of Accra. In Elmina, fisheries and boatbuilding are the major sources of income. A sheltered, accessible harbour is thus of great importance. A couple of years ago the main breakwater was repaired, a new lee breakwater was constructed and the harbour was deepened to offer a better accessible, but also sheltered harbour (Figure 8). However, after half a year, quite some sedimentation took place (see figure 9 and 10), creating a hazardous situation for vessels entering the harbour at low tide. Due to the long swell waves and the narrow channel between the breakwaters, vessels turning a bit too slow risk to be thrown against the lee breakwater.

To indentify the cause of this sedimentation problem, an XBeach model was constructed to get more insight into all wave driven sedimentation processes near Elmina harbour.
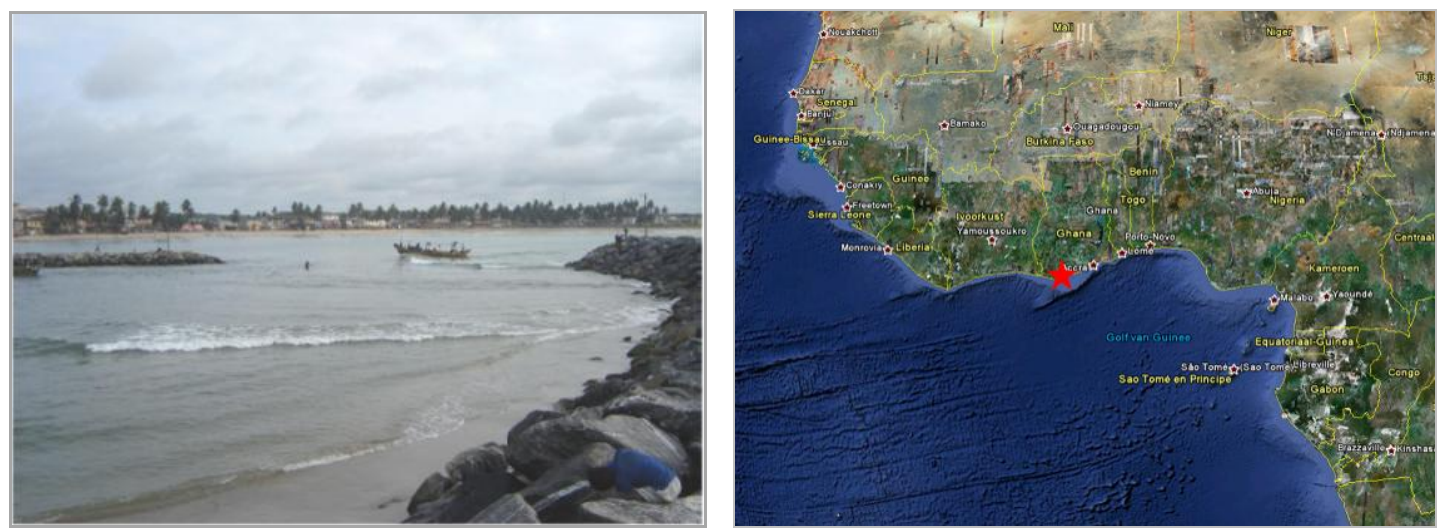

Figure 8. Field site 3: Elmina, Ghana (left: harbour entrance, right: location in west Africa).

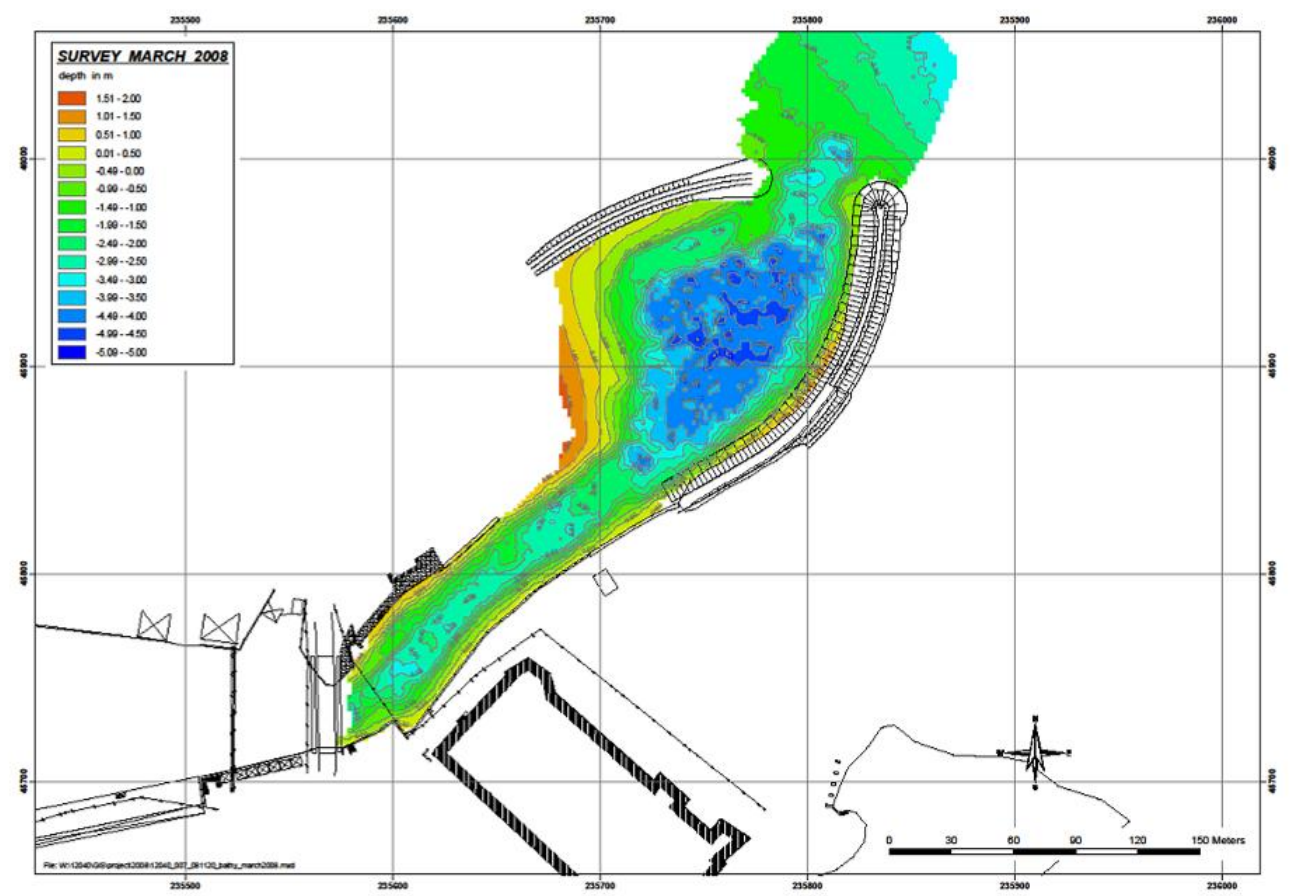

Figure 9. Bathymetry after construction of the breakwaters and dredging inside Elmina harbour (March 2008). 


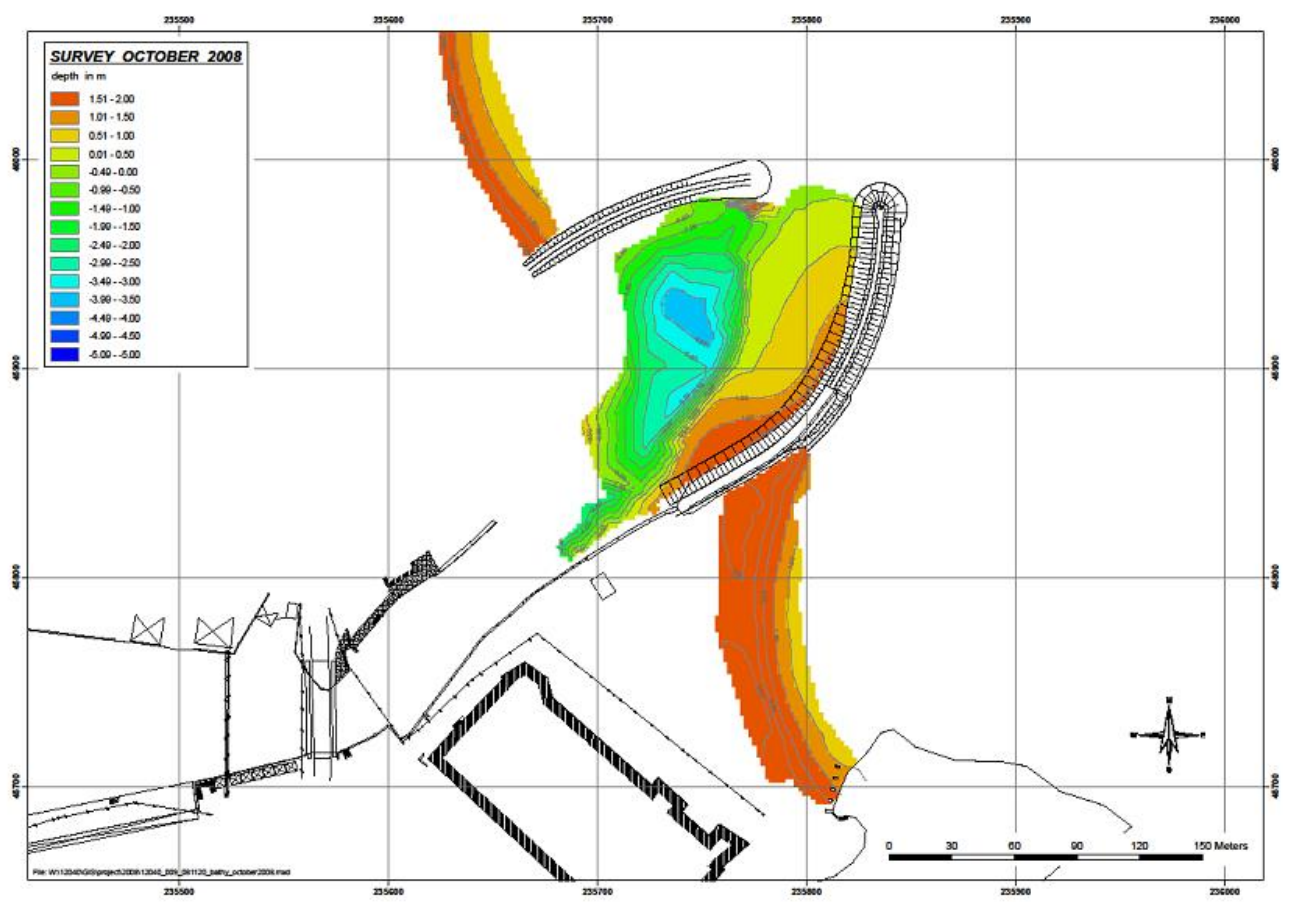

Figure 10. Bathymetry half a year after construction of the breakwaters and dredging inside Elmina harbour (October 2008).

\section{The model}

$\mathrm{XBeach}$ is applied in 2D mode. The model has a variable rectangular grid $(\mathrm{dx}=2$ to $20 \mathrm{~m}, \mathrm{dy}=10$ to $50 \mathrm{~m}$, total of $144 \times 96$ cells), with smaller grid cells in the zone of interest, near the breakwaters (see figure 11). The main and lee breakwater are included in the model as hard structures (or non-erodible layers). This means that the breakwaters are assumed to be non-porous.

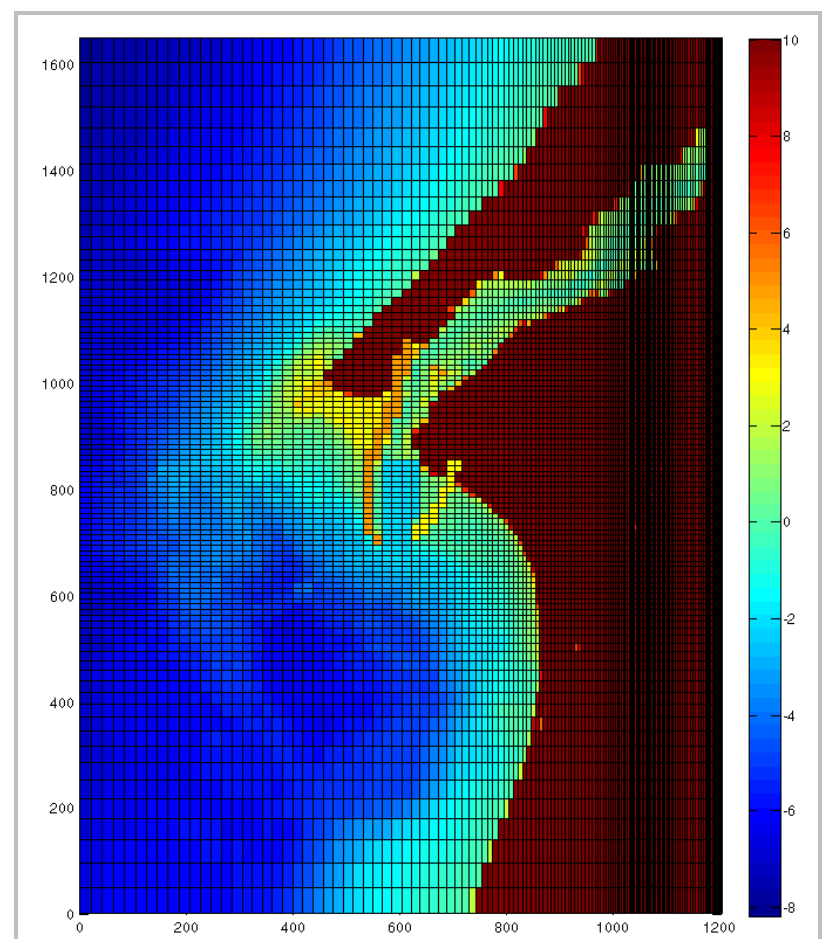

Figure 11. Grid of the Elmina 2D XBeach model. The colour scale shows the bathymetry [m LAT]. 
Simulations include the tidal water level variation and typical wave characteristics near Elmina (i.e. $\mathrm{Hs}=1.5 \mathrm{~m}$ and $\mathrm{Tp}=9 \mathrm{~s}$, with a direction of between 120 and $210^{\circ}$ degrees). All examples presented hereafter are the results for wave direction $150^{\circ}$. Important is that XBeach includes the long wave effects.

\section{Model results}

The model has been run during a tidal cycle to study the evolution of the current patterns and the sediment concentrations during inflow and outflow. Figure 12 shows the water level (colour scale) and the current pattern (arrows) at different stages of the tide. At low water (figure on top) currents are clearly coming from the south, with only a tiny component entering the harbour. When the tide is rising (figure in the middle), there is a clear inflow into the harbour, continuing up to high tide (figure at the bottom). Looking at the sediment concentrations (see figure 13) at becomes clear that there is possibly an inflow of sediments during rising tide.

The model has been run with this typical conditions for about a month, producing the erosion / sedimentation pattern shown in figure 14. This pattern show clearly sedimentation just in front of the harbour entrance. In between the two breakwaters, there is also some sedimentation (although less than outside the harbour), but inside the harbour there occurs no sedimentation at all. Apparently, the tide and wave-driven currents are not the (main) source of sediments inside the harbour.

Since the amount of sediments entering the harbour in between the breakwaters is not very much, the point of focus was shifted towards the main breakwater (i.e. the southern breakwater). This breakwater consists of the remains of an old, partially destroyed breakwater, which was restored by putting on a new armour layer. However, if there are some problems with the inside of the structure, for example being too porous, this could also explain the sedimentation problem. A very porous breakwater would allow sand too pass through the structure.

To test this hypothesis, a number of cross-sections were selected in the XBeach model across the main breakwater. The cross-sections are indicated on figure 15. For each of these cross-sections, a number of parameters were compared on the inside and on the outside of the breakwater. Figure 16 shows a number of graphs for cross-section SV50. On these graphs the time series for points A (outside) and point $\mathrm{C}$ (inside) are compared.

The graph on top shows for both points the time series for the bottom and water level. On the second graph, the water level difference (outside - inside) is shown. It is remarked that the water level outside the harbour is always higher than inside. This difference is about 5 to $10 \mathrm{~cm}$ and causes a gradient from the outside towards the inside. If the breakwater would be porous, this gradient could cause a flow from the outside towards the inside. Since wave breaking occurs on the beach just south of the main breakwater, sediment concentrations are high and as a result this flow could probably carry sediment into the harbour.

The graphs at the bottom show the comparison for the wave height. As could be expected, the wave height inside the harbour is always smaller than outside.

The other two cross-sections (SV110 \& SV160) give comparable results, although the strength of the gradient diminishes towards the end of the breakwater (results not shown here). 

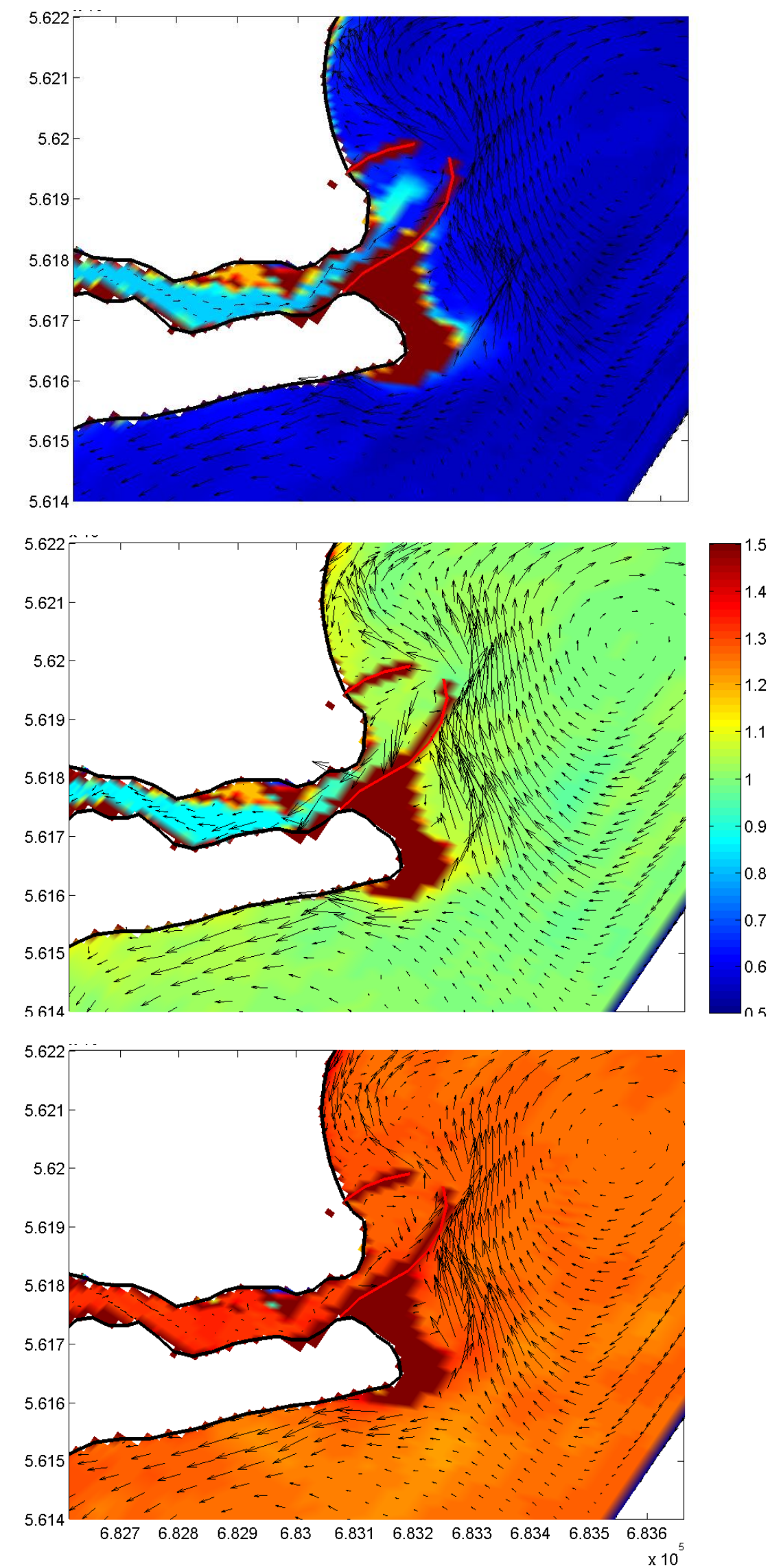

Figure 12. Current pattern due to tide and waves during ebb (arrows), on the background the water level (colour scale, $\mathrm{m}$ LAT). On top: low tide; in the middle: rising tide; at the bottom: high tide. 


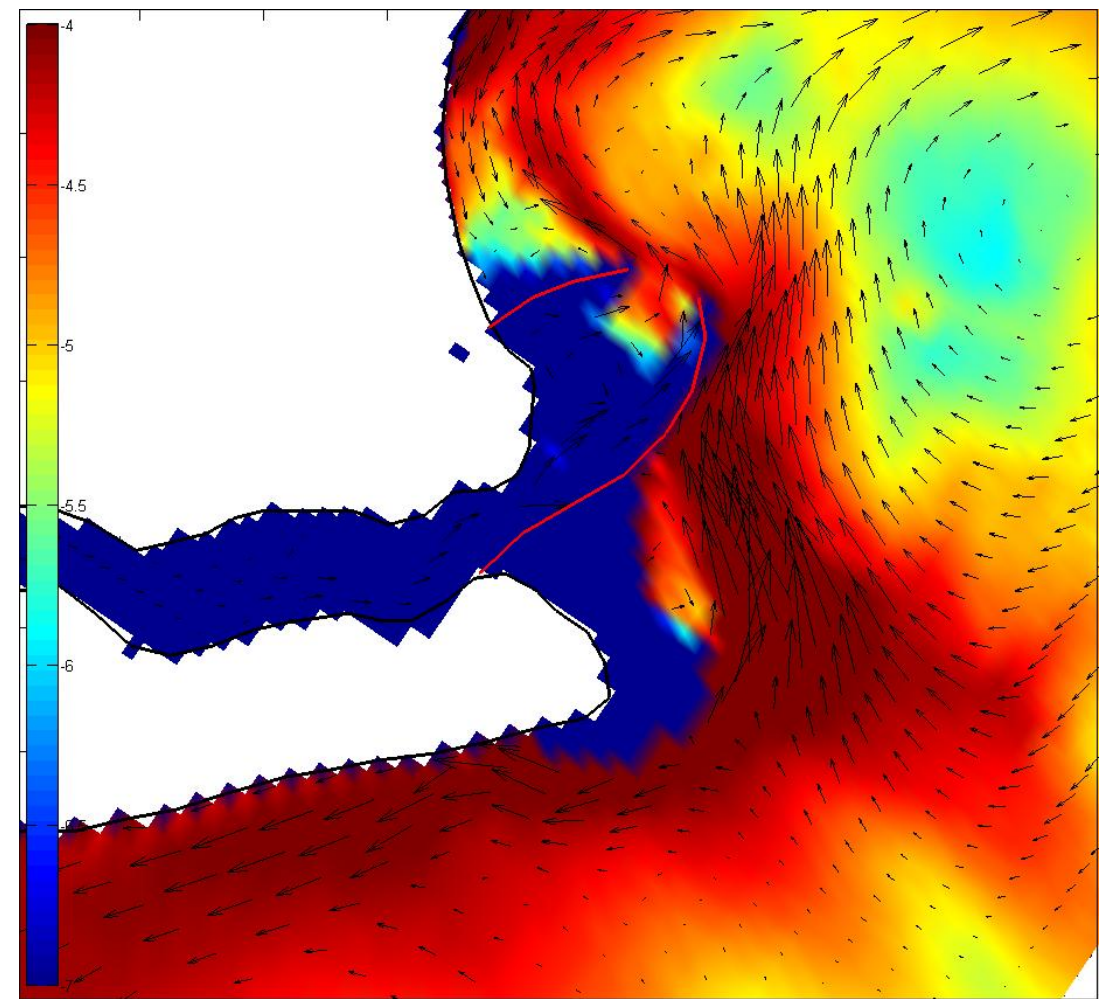

Figure 13. Current pattern due to tide and waves during ebb (arrows) with on the background the sediment concentration (in colour, on a log scale).

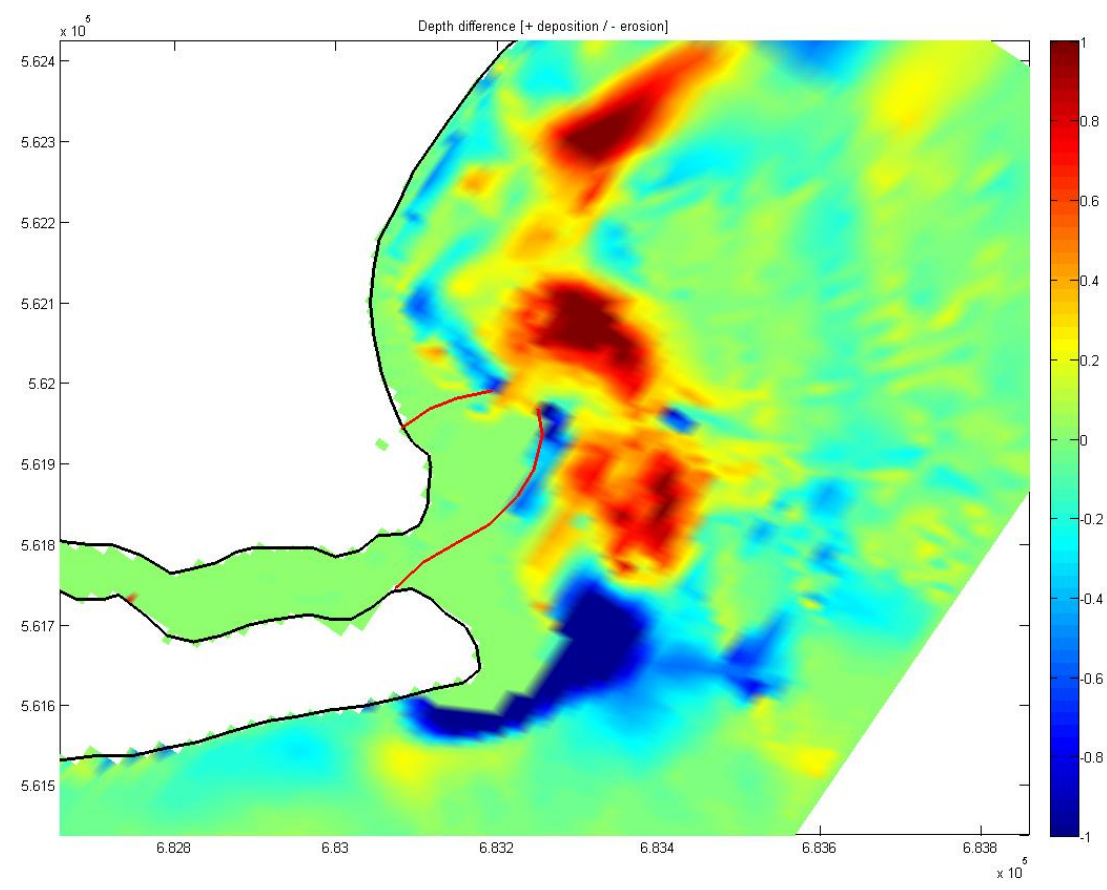

Figure 14. Erosion (blue) / sedimentation (red) pattern [m]. 


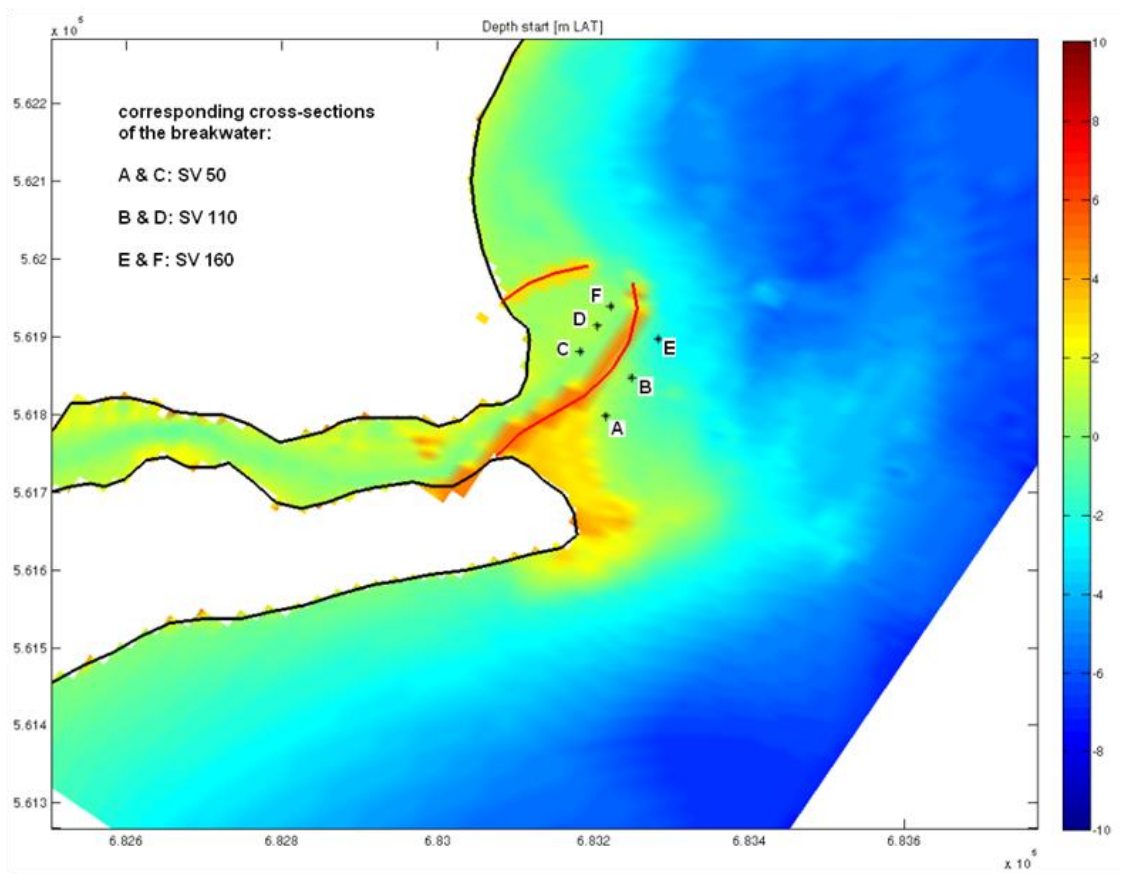

Figure 15. Location of the cross-sections; background: bathymetry (colour scale, m LAT).
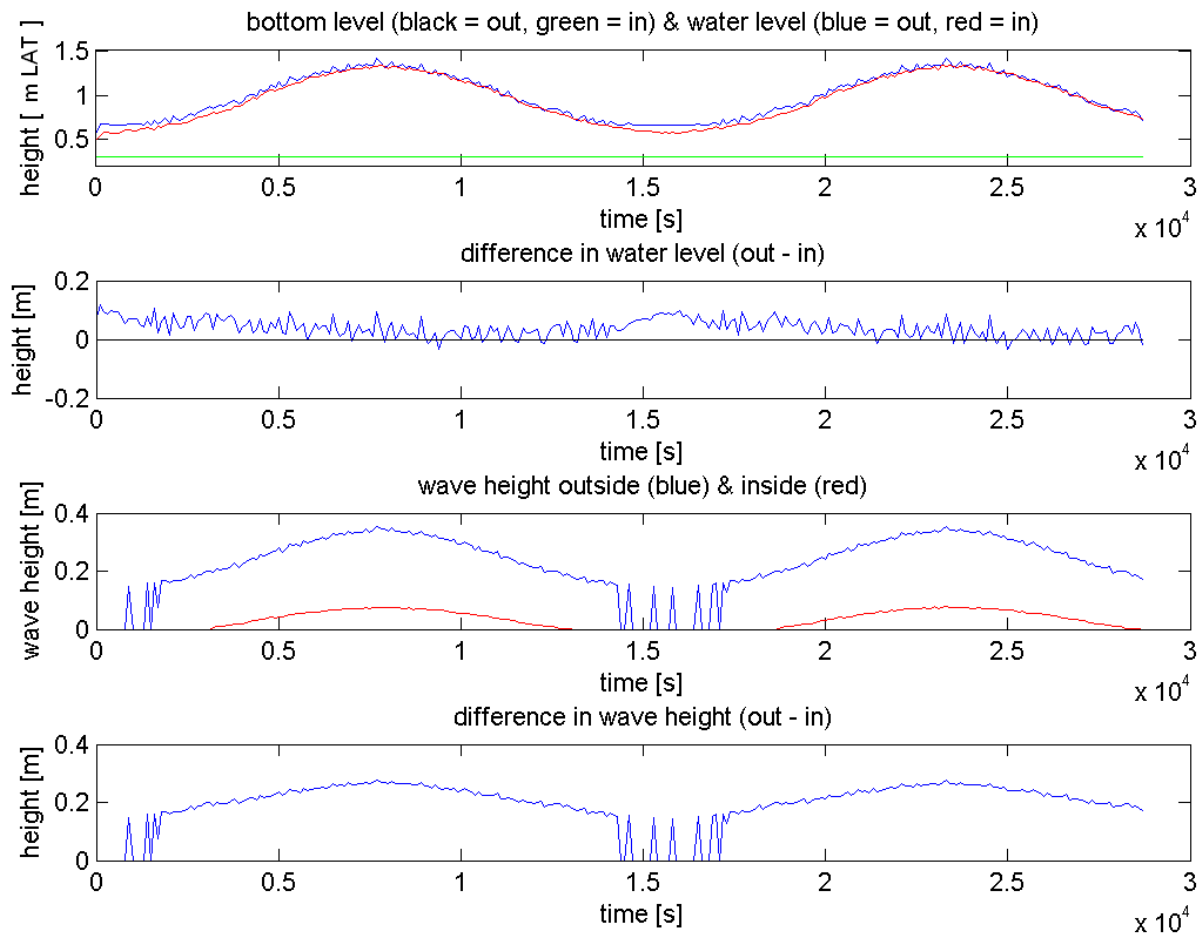

Figure 16. Comparison of bottom levels, water levels and wave heights inside and outside the main breakwater for cross-section A-C.

To test the hypothesis of the porous breakwater in the field, dye tests were performed. By releasing some dye in the water, the current is made visible. Figure 17 shows the result of the dye test performed at high water. From the five samples released on the outside of the lain breakwater, three of them were identified as flowing towards and through the breakwater. The other two samples (towards the end of the breakwater) showed a current along the breakwater, going towards the north. This confirms not only the results of the XBeach model, but also the assumption of the porous breakwater. 


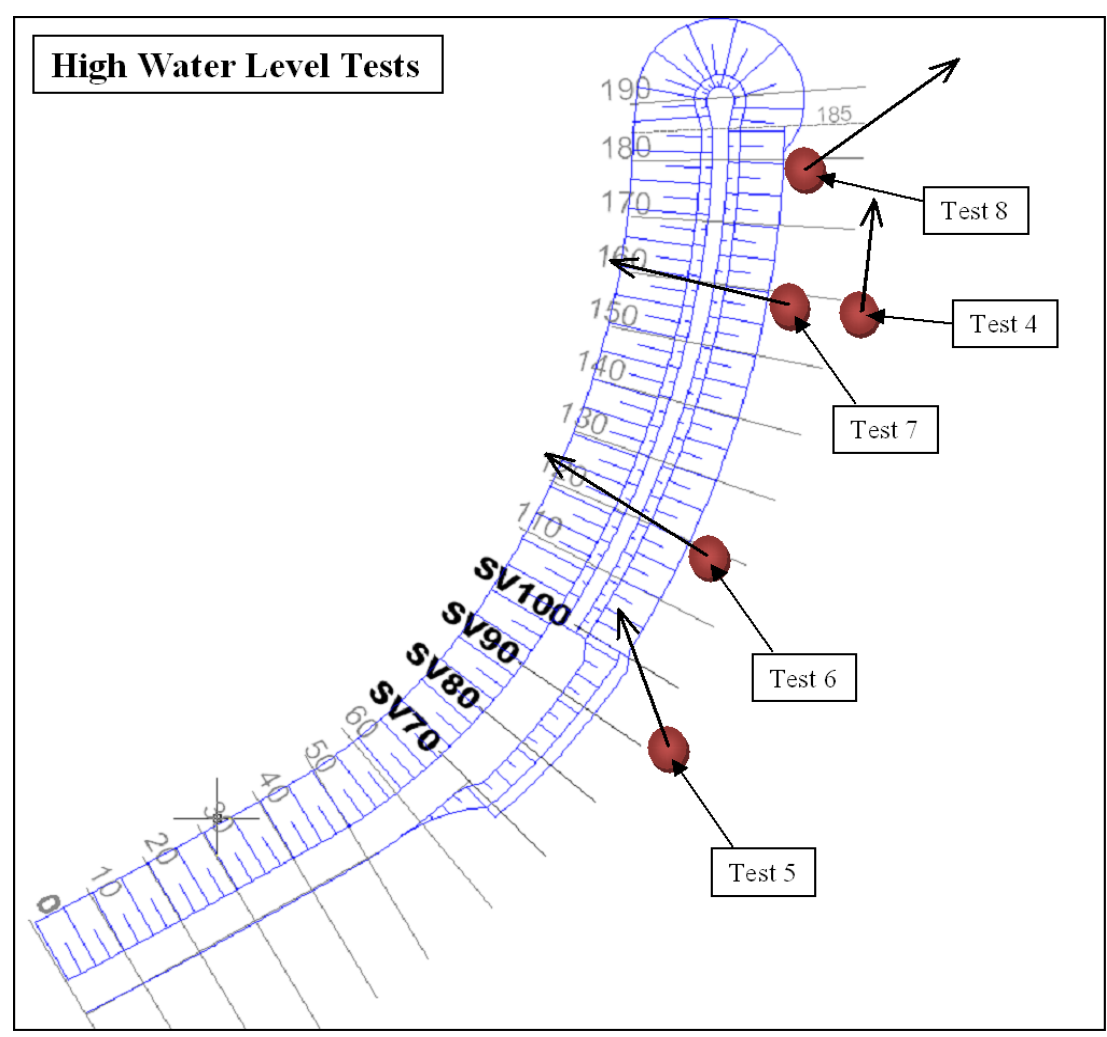

Figure 17. Result of the dye tests performed at high water.

As a remedial measure, a high number of big bags were filled with sand from the beach and were placed alongside the main breakwater. Bags were placed both on the inside as on the outside from the breakwater and starting as low as possible. The excessive amount of sand in the harbour was dredged, creating a wider entrance channel.

Surveys after these measures clearly showed the positive effect of the sand bags: the sedimentation was far less and the channel remained open. This once again proved that the sedimentation problem can be solved by making the breakwater less permeable.

\section{CONCLUSIONS}

The XBeach model was tested for different cases. The first one, the Ostend case in Belgium, was a typical case for XBeach: beach erosion during storm conditions. For the November 2007 storm, the model results of XBeach (1D) were compared with the measurements, but also with the results from the off-the-shelf 1D model Durosta. The results from XBeach were as least as good as from Durosta for this storm event, and the location of the erosion front was slightly better predicted. However, the main advantage of XBeach for this application is the possibility to include the $2 \mathrm{D}$ effects. For the curved sections of the beach, the higher amounts of erosion in reality also came out of the model.

For the Ada case in Ghana the XBeach model will be applied to test a new coastal protection scheme under long wave attack. This study is still going on due to late delivery of the measurements.

The third case was the application of XBeach for the study of the sedimentation processes in a shallow coastal harbour in Elmina, Ghana. The 2D model was able to give insight into the complex mechanisms and to identify the most important one. Wave breaking and run-up on the beach just south of the main breakwater created a water level gradient towards the inside. In the case of a porous breakwater, this creates an inflow of sediments into the harbour. Remedial measures preventing this inflow proved to be effective and significantly decreased the sedimentation. 


\section{ACKNOWLEDGMENTS}

We would like to thank the Coastal Division of the Flemish government for providing the data (topography, bathymetry and hydrodynamic measurements) related to the Ostend case in Belgium. Furthermore we would like to acknowledge the funding received in the framework of the MICORE project (www.micore.eu), which is part of: the EU Environment research programme - Sub-activity Natural Hazards (http://ec.europa.eu/research/environment/index_en.cfm?pg=hazards) and the FP7 Framework programme and Calls (http://cordis.europa.eu/fp7/home_en.html).

\section{REFERENCES}

Andrews, D.G. and McIntyre, M.E., 1978. An exact theory of nonlinear waves on a Lagrangian-mean flow. Journal of Fluid Mechanics, 89(4): 609-646.

Galappatti, R. and Vreugdenhil, C.B. (1985), A depth integrated model for suspended transport, Journal of Hydraulic Research, 23(4), 359-377.

Roelvink, J.A, A. Reniers, A. van Dongeren, J. van Thiel de Vries, R. McCall , J. Lescinski. 2009. Modeling storm impacts on beaches, dunes and barrier islands. Submitted to Coastal Engineering.

Soulsby, R. L. (1997), Dynamics of Marine Sands, Thomas Telford, London.

Steetzel, H.J. 1993. Cross-shore transport during storm surges. Ph.D. Thesis Delft University of Technology. ISBN 9090063455.

Trouw K., Lerouge P., Hoffman, Bollen M, De Kesel Y, Gruwez V., Mercelis P., Bolle A., 2010. Design of a coastal protection scheme for Ada at the Volta-River mouth. ICCE, 2010.

Van Dongeren A., Bolle A., Vousdoukas M.I., Plomaritis T., Eftimova P., Williams J., Armaroli C., Idier D., Van Geer P., Van Thiel de Vries J., Haerens P., Taborda R., Benavente J., Trifonova E., Ciavola P., Balouin Y., Roelvink D. 2009. Micore: Dune erosion and overwash model validation with data from nine European field sites. Coastal dynamics 2009. 